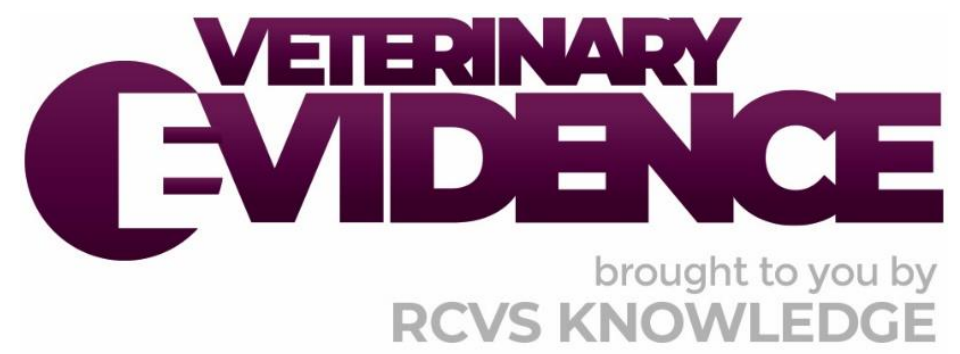

\title{
Does the Use of Intratesticular Blocks in Dogs Undergoing Orchiectomies Serve as an Effective Adjunctive Analgesic?
}

\section{A Knowledge Summary by}

Erik Fausak MSLIS, MA, LVT, RLAT ${ }^{1}$

Elizabeth Rodriguez LVT, $\mathrm{CVT}^{1}$

Anna Simle Student ${ }^{1^{*}}$

Netwarat Merman Student MBA ${ }^{1}$

Dakota Cook Student ${ }^{1}$

\footnotetext{
${ }^{1}$ Bel-Rea Institute of Animal Technology, 1681 S. Dayton St. Denver, CO 80247, USA

* Corresponding Author (asimle@gmail.com)
}

ISSN: 2396-9776

Published: 10 Dec 2018

in: Vol 3, Issue 4

DOI: http://dx.doi.org/10.18849/ve.v3i4.206

Reviewed by: Dick White (BVetMed PhD DSAS DVR DipACVS

DipECVS FRCVS) and Bruce Smith (BVSc MS FANZCVS DACVS)

Next Review Date: Dec 10th 2020 


\section{KNOWLEDGE SUMMARY}

\section{PICO question}

In dogs undergoing orchiectomy, does the use of intratesticular blocks reduce the pain in patients compared to not using intratesticular blocks?

Clinical bottom line

Low level of evidence suggests that when compared to a pre-medication with pure- $\mu$ agonist opioids, intratesticular blocks do not appear to provide significant benefit. However, based on our clinical scenario where pre-medication is with a partial- $\mu$ opioid like buprenorphine, there may be benefit in utilising intratesticular lidocaine or bupivicaine.

\section{Clinical Scenario}

While animals don't appear to show a great deal of pain on our pain scale in post orchiectomies, does the use of intratesticular lidocaine work as a good adjunctive analgesic compared to not using it, and are there many severe complications?

\section{Summary of the evidence}

\section{Stevens et al. (2013)}

\begin{tabular}{|c|l|}
\hline Population: & $\begin{array}{l}\text { Shelter dogs at least } 4 \text { months of age (determined by dentition or } \\
\text { record), in general good health without requiring additional } \\
\text { procedures and no signs of testicular or scrotal disease. Mean age } \\
\text { was about } 2 \text { years old and average weight about } 18 \mathrm{~kg} .\end{array}$ \\
\hline Sample size: & $\begin{array}{l}38 \text { dogs were initially entered into the study but follow up data was } \\
\text { lost on } 5 \text { dogs (they wanted } 40 \text { for a power of } 0.8) \text {. Dogs were } \\
\text { separated into two groups : } \\
\text { Placebo group 1 ( } \mathrm{n}=16) \text { and lidocaine/bupivacaine treatment group } \\
2 \text { (n=17) }\end{array}$ \\
\hline Intervention details: & $\begin{array}{l}\text { All animals were induced and maintained with the same protocol: } \\
\text { Premed: } \\
\text { Morphine } 0.5 \mathrm{mg} / \mathrm{kg} \mathrm{IM} \\
\text { Acepromazine } 0.025 \mathrm{mg} / \mathrm{kg} \mathrm{IM} \\
\text { Induction (20-45 minutes later): } \\
\text { Tiletamine and zolazepam } 0.22 \mathrm{ml} / \mathrm{kg} \\
\text { Intubated } \\
\text { Maintenance: }\end{array}$ \\
\hline
\end{tabular}




\begin{tabular}{|c|c|}
\hline & $\begin{array}{l}\text { Isoflurane } \\
\text { A certified veterinary technician recorded parameters and } \\
\text { documented at } 5 \text { minute intervals. Parameters included: heart rate, } \\
\text { respiratory rate, mucous membrane colour, pulse oximetry, } \\
\text { isoflurane concentration, and oxygen flow rate. } \\
\text { A third party randomly assigned animals. } \\
\text { Group } 1 \text { (n=16) received an equivalent volume to body weight of } \\
\text { saline intratesticularly } \\
\text { Group } 2 \text { (n=17) received } 1 \mathrm{mg} / \mathrm{kg} \text { of bupivacaine and } 1 \mathrm{mg} / \mathrm{kg} \text { of } \\
\text { lidocaine (combined) intratesticularly. } \\
\text { Every animal received } 1 / 3 \text { to } 1 / 2 \text { of the volume drawn up in each } \\
\text { testicle. All parties involved in scoring were blinded to which } \\
\text { received placebo or treatment by mixing volumes and delivering to } \\
\text { all animals. } \\
\text { Intratesticular technique: } 22 \mathrm{~g} 1 \text { inch needles were used where the } \\
\text { needle was placed at the caudal pole of the testis and the needle } \\
\text { was directed toward the spermatic cord. All syringes were aspirated } \\
\text { and the needle was slowly pulled out while } 1 / 3 \text { to } 1 / 2 \text { of the syringe } \\
\text { volume was placed in each testicle. } \\
\text { Standard castration was performed (technique not specified if } \\
\text { prescrotal or scrotal) } \\
\text { Post-operatively, every dog received } 4.4 \mathrm{mg} / \mathrm{kg} \text { carprofen sQ and } \\
\text { dogs were evaluated for pain at } 15 \mathrm{~min}, 1 \mathrm{hr}, 2 \mathrm{hr} \text {, and } 24 \mathrm{hr} \text { post- } \\
\text { operatively. }\end{array}$ \\
\hline Study design: & Blinded randomised control trial \\
\hline Outcome studied: & $\begin{array}{l}\text { Perioperatively parameters were monitored and cremastor twitch } \\
\text { response was recorded during the surgical procedure. } \\
\text { Dogs were evaluated for pain at } 15 \mathrm{~min}, 1 \mathrm{hr}, 2 \mathrm{hr} \text {, and } 24 \mathrm{hr} \text { post- } \\
\text { operatively. Pain score evaluation was done utilising a modified VAS } \\
\text { pain scale used by Sammarco et al. 1996: } \\
\text { Scale was given on } 6 \text { criteria: comfort, movement, appearance, } \\
\text { vocalisation, heart rate, and respiratory rate from a range of } 0 \text { - } 12 \\
\text { where } 12 \text { is most painful. } \\
\text { Any animal with a score equal or over six received rescue analgesia } \\
\text { of either morphine ( } 0.5 \mathrm{mg} / \mathrm{kg} \text { IM) or tramadol (1-2 mg/kg PO). } \\
\text { Sites were also evaluated for bruising and swelling on a visual } \\
\text { analogue scale of 0-3, } 3 \text { being the most bruised or swollen. }\end{array}$ \\
\hline
\end{tabular}




\begin{tabular}{|c|c|}
\hline $\begin{array}{l}\text { Main findings: } \\
\text { (relevant to PICO question): }\end{array}$ & $\begin{array}{l}\text { - } 1 / 16 \text { dog in the placebo group and } 8 / 17 \text { in the } \\
\text { lidocaine/bupivacaine did not demonstrate cremastor } \\
\text { twitch. } \\
\text { - No statistical significance in any pain scorings between } \\
\text { groups ( } 4 / 17 \text { had successful (low) pain scores in } \\
\text { lidocaine/bupivicaine group compared to } 1-2 / 16 \text { in control } \\
\text { group. all groups had the exact same pain scores } 120 \\
\text { minutes after surgery. } \\
\text { - Surgical bruising and edema did not have significance, group } \\
2 \text { had one swelling score of } 2 \text { (highest level of the two } \\
\text { groups), but all other scores were similar. Both groups did } \\
\text { not have bruising. }\end{array}$ \\
\hline Limitations: & $\begin{array}{l}\text { - The pain scale was not validated. } \\
\text { - Recovery times were not compared. } \\
\text { - } \quad \text { Blood pressure was not recorded. } \\
\text { - Not sure what cremastor twitch is supposed to represent, } \\
\text { the efficacy of the intratesticular absorption of lidocaine and } \\
\text { bupivacaine? Or is this a reflection of pain response } \\
\text { perioperatively? } \\
\text { - If } 40 \text { dogs were needed for a good power ( } 0.8) \text {, the sample } \\
\text { size falls well below that. } \\
\text { Early scores of analgesia, despite no statistical significance, } \\
\text { was clearly clinically relevant as they were two to four times } \\
\text { better than the placebo group. }\end{array}$ \\
\hline
\end{tabular}

\section{Rodriguez et al. (2016)}

\begin{tabular}{|c|l|}
\hline Population: & $\begin{array}{l}\text { Client-owned dogs averaging } 3 \text { years with weights between } 6 \text { and } 30 \\
\text { kg but averaging } 18 \mathrm{~kg} . \text { Exclusion criteria included cryptorchid, any } \\
\text { testicular abnormalities, brachycephalics, aggressive behaviour, or } \\
\text { extreme anxiety, and any dogs that were not American Society of } \\
\text { Anesthesiologists( ASA) anesthetic risk status of } 1 \text { or } 2 .\end{array}$ \\
\hline Sample size: & 31 dogs \\
\hline Intervention details: & $\begin{array}{l}\text { Group } 1 \text { ( } \mathrm{n}=11) \text { intratesticular lidocaine at } 2 \mathrm{mg} / \mathrm{kg}(1 \mathrm{mg} / \mathrm{kg} \text { for each } \\
\text { testicle) } \\
\text { Group } 2 \text { ( } \mathrm{n}=10) \text { same dose of lidocaine, but intrafunicular instead of } \\
\text { intratesticular. } \\
\text { Group } 3 \text { ( } \mathrm{n}=10) \text { control group received saline equivalent to lidocaine } \\
\text { amount intratesticular. }\end{array}$ \\
\hline
\end{tabular}




\begin{tabular}{|c|c|}
\hline & $\begin{array}{l}\text { All animals were premedicated with: } \\
\text { Acepromazine } 0.2 \mathrm{mg} / \mathrm{kg} \text { IM } \\
\text { Meloxicam } 0.3 \mathrm{mg} / \mathrm{kg} \text { IV } \\
\text { Tramadol } 3 \mathrm{mg} / \mathrm{kg} \text { IV } \\
\text { Induction and maintenance: } \\
\text { Ketamine induction } 5 \mathrm{mg} / \mathrm{kg} \text { and maintenance with ketamine } \\
\text { boluses of } 2.5 \mathrm{mg} / \mathrm{kg} \text {. } \\
5 \text { minutes after induction all animals had the scrotum aseptically } \\
\text { prepared. All animals received lidocaine (0.33mg/kg) SQ in the } \\
\text { scrotal incision site. All groups had injections performed with } 22 \mathrm{~g} 1 \\
1 / 2 \text { “ needles. They were then subdivided into three groups: } \\
\text { Group } 1 \text { ( } \mathrm{n}=11 \text { ) intratesticular lidocaine at } 0.66 \mathrm{mg} / \mathrm{kg} \text { of lidocaine in } \\
\text { each testicle. Placed in the body of the testicle based on Mcmillan } \\
\text { (2012). } \\
\text { Group } 2 \text { ( } \mathrm{n}=10 \text { ) same dose of lidocaine, but intrafunicular instead of } \\
\text { intratesticular. Placed as close as possible to the external inguinal } \\
\text { canal from Suriano et al. ( } 2014 \text { ). } \\
\text { Group } 3 \text { ( } \mathrm{n}=10 \text { ) control group received saline equivalent to lidocaine } \\
\text { amount intratesticular. Placed in the body of the testicle based on } \\
\text { McMillan ( } 2012 \text { ). } \\
\text { All groups had sodium bicarbonate mixed with all injections at a ratio } \\
1: 10 \text { volume. } \\
\text { During procedure rescue analgesics of fentanyl } 5 \mu \mathrm{g} / \mathrm{kg} \text { IV was } \\
\text { delivered if ketamine was considered insufficient and the animal } \\
\text { showed significant changes in respiration, cardiovascular (heart rate } \\
\text { or blood pressure), movement, and if vocalisation was present. }\end{array}$ \\
\hline Study design: & Randomised controlled, blinded trial. \\
\hline Outcome studied: & $\begin{array}{l}\text { Perioperatively monitored by veterinary staff with blood pressure } \\
\text { (oscillometric), pulse oximetry, HR, and RR. } \\
\text { Times of monitoring T0 ( } 5 \text { minutes after induction), T1 (incision into } \\
\text { scrotal body (left)), T2 (retraction of spermatic cord), T3 (pinching } \\
\text { and cutting spermatic cord), T4 (incision into scrotum (right)), T5 } \\
\text { (retraction of second testicle), T6 (Pinching and cutting of spermatic } \\
\text { cord) recorded on excel spreadsheet. }\end{array}$ \\
\hline
\end{tabular}




\begin{tabular}{|c|c|}
\hline $\begin{array}{l}\text { Main findings: } \\
\text { (relevant to PICO question): }\end{array}$ & $\begin{array}{l}\text { Respiratory, significant changes were noticed at T1 and T5. } \\
\text { Intrafunicular had the least change in respiration compared to the } \\
\text { other techniques except the control group had the least change at } \\
\text { T5. } \\
\text { In heart rate, the intratesticular group had the least changes except } \\
\text { for T2 where intrafunicular had the least change and intratesticular } \\
\text { lidocaine had the greatest change. } \\
\text { Mean arterial pressure, the control group showed the least change } \\
\text { in blood pressure with the exception of T2 where the intrafunicular } \\
\text { group had the least change. } \\
\text { Ketamine and fentanyl were least supplemented in the lidocaine } \\
\text { intratesticular (ketamine) and intrafunicular (fentanyl) groups and } \\
\text { no significant difference between lidocaine intratesticular and } \\
\text { intrafenicular groups were found, but there was a difference from } \\
\text { control groups. } \\
\text { Qualitative differences in terms of haematoma, bleeding, dysphoria, } \\
\text { movement on the table, and cremastor contraction were not } \\
\text { significant. }\end{array}$ \\
\hline Limitations: & $\begin{array}{l}\text { - The graphs were difficult to read because they used percent } \\
\text { changes instead of absolute numbers. } \\
\text { - Did no post-operative evaluation. } \\
\text { - Not described how the study was randomised }\end{array}$ \\
\hline
\end{tabular}

McMillan et al. (2012)

\begin{tabular}{|c|l|}
\hline Population: & $\begin{array}{l}\text { Client-owned } 6 \mathrm{mos}-8 \text { yo dogs receiving elective castration and } \\
\text { judged healthy on physical exam by the lead investigator. Exclusion } \\
\text { - aggressive behavior, adverse reactions to NSAIDS, and previous } \\
\text { painful condition. }\end{array}$ \\
\hline Sample size: & 30 dogs \\
\hline Intervention details: & $\begin{array}{l}\text { All animals were premedicated with } 0.03 \mathrm{mg} / \mathrm{kg} \text { acepromazine, } 0.02 \\
\mathrm{mg} / \mathrm{kg} \text { buprenorphine, and injected IM in cervical epaxial muscles. } \\
\text { All animals had a } 22 \mathrm{~g} \text { catheter and } 2-4 \mathrm{mg} / \mathrm{kg} \text { propofol induction. } \\
\text { All animals were intubated and maintained with isoflurane and put } \\
\text { on IV fluids at } 10 \mathrm{ml} / \mathrm{hr} . \text { After induction, } 4 \mathrm{mg} / \mathrm{kg} \text { carprofen was } \\
\text { given intravenously. } \\
\text { After intubation animals were prepared pre-scrotal castration, dogs } \\
\text { were assigned to two groups: }\end{array}$ \\
\hline
\end{tabular}




\begin{tabular}{|c|c|}
\hline & $\begin{array}{l}\text { using a one inch, } 22 \mathrm{~g} \text { needle. Lidocaine injection was stopped if } \\
\text { testicle was hard and firm. } \\
\text { Control - dogs received no additional treatment. } \\
\text { Patients were warmed on a hot dog patient warming system. Before } \\
\text { skin closure lidocaine at } 1 \mathrm{mg} / \mathrm{kg} \text { was administered as an incisional } \\
\text { splash block if they already received lidocaine. } \\
\text { Isoflurane over } 2.1 \% \text { required rescue analgesia } 1 \mu \mathrm{g} / \mathrm{kg} \text { fentanyl IV, } \\
\text { animals were supposed maintained on } 1.3 \% \text { isoflurane. } \\
0.02 \mathrm{mg} / \mathrm{kg} \text { buprenorphine was given IV before patients were } \\
\text { discharged. }\end{array}$ \\
\hline Study design: & Randomised Control Trial \\
\hline Outcome studied: & $\begin{array}{l}\text { ECG, respired gasses, pulse oximetry, esophageal temperature, and } \\
\text { Doppler blood pressure. HR, RR, SBP, ETCO2, Iso concentration, and } \\
\text { vaporizer setting was recorded. } \\
\text { T0 baseline } \\
\text { T1 first skin incision } \\
\text { T2 clamping first testicular pedacles } \\
\text { T3 Clamping second testicular pedacles. } \\
\text { T4 when } 1^{\text {st }} \text { skin suture was placed } \\
\text { Unblended postoperative pain scores were assessed. }\end{array}$ \\
\hline $\begin{array}{l}\text { Main findings: } \\
\text { (relevant to PICO question): }\end{array}$ & $\begin{array}{l}\text { - No statistically significant changes in isoflurane early on, but } \\
\text { the lidocaine group had lower isoflurane settings than the } \\
\text { first group when castration was in process. }\end{array}$ \\
\hline
\end{tabular}




\begin{tabular}{|l|l|l|}
\hline & $\begin{array}{l}\text { A spot of blood on all intratesticular injections and some } \\
\text { haematomas were noticed after testicular injection as } \\
\text { negative side effects of intratesticular injection. }\end{array}$ \\
\hline Limitations: & $\begin{array}{l}\text { Post-operative pain scores were lowest in intratesticuar } \\
\text { lidocaine groups } 7 / 15 \text { of the control required rescue } \\
\text { analgesia as opposed to } 1 / 15 \text { of the lidocaine group. }\end{array}$ \\
\hline - $\begin{array}{l}\text { Unblended observation of pain score. } \\
\text { Inadequate blinding procedure with control group not } \\
\text { receiving any injection. } \\
\text { Student veterinarians doing the procedure may be } \\
\text { unnecessarily longer compared to clinical practice. }\end{array}$ \\
\end{tabular}

\begin{tabular}{|c|c|}
\hline \multicolumn{2}{|l|}{ Perez et al. (2013) } \\
\hline Population: & $\begin{array}{l}\text { Healthy Male intact dogs from shelters aged } 4 \text { mos- } 4 \text { years old, } \\
\text { greater than } 4.5 \mathrm{~kg} \text {, Healthy based on physical exam, PCV and TP } \\
\text { results. Aggressive and fearful animals were excluded. Dogs with } \\
\text { conditions to preclude epidural administration of drugs were also } \\
\text { excluded. Surgeries greater than three hours or with a great deal of } \\
\text { complications were excluded. }\end{array}$ \\
\hline Sample size: & 51 dogs \\
\hline Intervention details: & $\begin{array}{l}\text { All animals were premedicated with carprofen } 4.4 \mathrm{mg} / \mathrm{kg} \\
\text { subcutaneously, acepromazine } 0.02 \mathrm{mg} / \mathrm{kg} \text {, and hydromorphone } 0.1 \\
\mathrm{mg} / \mathrm{kg} \text { were combined and given IM. } \\
\text { All dogs were administered propofol induction } 3.4-5.5 \mathrm{mg} / \mathrm{kg} \text { and } \\
\text { intubated. All dogs were maintained with isoflurane, starting at } 3 \% \\
\text { and adjusted accordingly. } \\
3 \text { treatment groups were arranged (randomisation of timestamps of } \\
\text { anesthesia forms): } \\
\text { control group ( } \mathrm{n}=17 \text { ) - received nothing besides their premed and } \\
\text { induction with maintenance agents. Saline was provided } \\
\text { intratesticularly and epidurally. } \\
\text { Epidural group ( } \mathrm{n}=17 \text { ) - morphine epidural was placed } 0.1 \mathrm{mg} / \mathrm{kg} \text {. } \\
\text { Saline was provided intratesticularly. } \\
\text { Intratesticular group ( } \mathrm{n}=17 \text { ) - bupivacaine was injected } 1 \mathrm{mg} / \mathrm{kg} \\
\text { intratesticularly. } 22 \mathrm{~g} 2.2 \mathrm{~cm} \text { needle was injected into the } \\
\text { parenchyma of each testes after aspiration of each injection. } 1 / 2 \text { the }\end{array}$ \\
\hline
\end{tabular}




\begin{tabular}{|c|c|}
\hline & $\begin{array}{l}\text { dose was in each testicle. Saline was provided epidurally. } \\
\text { Rescue analgesics (fentanyl } 2 \mu \mathrm{g} / \mathrm{kg} \text { ) were provided intraoperatively } \\
\text { when a noxious stimulus resulted in heart rate, respiratory rate, and } \\
\text { mean blood pressure greater than or equal to } 20 \% \text { including } \\
\text { anaesthetist experience. } \\
\text { Post-operative pain was evaluated by modified Glasgow pain scale } \\
\text { (short form). Pain was evaluated when the animal could raise its } \\
\text { head, or responded when incisional site is manipulated. After initial } \\
\text { exam, pain scores were evaluated at } 1 \text { hour and } 4 \text { hour interval. Pain } \\
\text { scale higher than } 5 \text { received rescue analgesics of hydromorphone } 0.1 \\
\mathrm{mg} / \mathrm{kg} \text { IV. Dexmedetomidine would be delivered at } 2 \mu \mathrm{g} / \mathrm{kg} \text { if the } \\
\text { pain score did not go down and the animal would be removed from } \\
\text { the study. }\end{array}$ \\
\hline Study design: & Blinded Randomised Control Trial \\
\hline Outcome studied: & $\begin{array}{l}\text { SEM weight, age, anaesthesia duration and surgery duration were } \\
\text { measured. End Tidal Isoflurane was measured, time for epidural and } \\
\text { intratesticular administration, rescue analgesics administered peri } \\
\text { and post operatively. Anesthetic values were utilised but not } \\
\text { presented in study. Pain scores were recorded, as well. Serum } \\
\text { cortisol was recorded in all patients prior to surgery, } 15 \text { minutes } \\
\text { after both testes were removed, and at } 1 \mathrm{~h} \text { and } 4 \mathrm{~h} \text { marks after } \\
\text { extubation. }\end{array}$ \\
\hline $\begin{array}{l}\text { Main findings: } \\
\text { (relevant to PICO question): }\end{array}$ & $\begin{array}{l}\text { Pain score at } 0 \text { and } 1 \text { hours were higher in the control group. } \\
\text { No significant difference in anaesthetic values (HR, RR, Mean or } \\
\text { systolic pressures), no significant difference in HR or RR in post- } \\
\text { operative group. Control group had higher blood pressures at the } 25 \\
\text { minute intraoperative measurement. } \\
\text { Significantly lower rescue analgesia occurred intraoperatively and } \\
\text { postoperatively in both experimental groups. Intratesticular group } \\
\text { needed a much larger quantity of post-operative rescue analgesia } \\
\text { but less intraoperatively compared to epidural anaesthesia. } \\
14 / 17 \text { control group animals needed post-operative analgesia, } 3 / 17 \\
\text { epidural group needed post-operative analgesia, and } 7 / 17 \text { in the } \\
\text { intratesticular group needed post-operative analgesia. } \\
\text { Serum cortisol was significantly lower for the intratesticular group } \\
\text { than control. }\end{array}$ \\
\hline Limitations: & $\begin{array}{l}\text { - Cortisol is a stress hormone but may not be an accurate } \\
\text { surrogate outcome of pain. } \\
\text { - Randomisation was not well explained. } \\
\text { - Anaesthesia values were not displayed in the results. }\end{array}$ \\
\hline
\end{tabular}


Huuskonen et al. (2013)

\begin{tabular}{|c|c|}
\hline Population: & $\begin{array}{l}\text { Male client-owned dogs weighing on average } 17.5 \mathrm{~kg} \text { and average } \\
\text { age } 14.3 \text { months. Inclusion was normal testicular anatomy and } \\
\text { relatively healthy American Society of Anesthesiologists (ASA) status } \\
\text { grade 1. Dogs were excluded if they needed additional procedures. }\end{array}$ \\
\hline Sample size: & 42 \\
\hline Intervention details: & $\begin{array}{l}\text { Animals were randomly assigned via random.org to: } \\
\text { Group L(n=19) - received intratesticular injection of } 2 \% \text { lidocaine at } \\
2 \mathrm{mg} / \mathrm{kg} \text { receiving } 1 / 3 \text { of volume in each testis and } 1 / 3 \mathrm{SQ} \text { in pre- } \\
\text { scrotal surgical site. } \\
\text { Group S ( } \mathrm{n}=23 \text { ) - control group received intratesticular injection of } \\
\text { saline identical in volume to Group } \mathrm{L} \\
\text { All injections were blinded to anaesthetist and surgeon, a syringe } \\
\text { was handed to the surgeon without their knowledge if it is saline or } \\
\text { lidocaine. All surgeons got a } 23 \times 11 / 4 \text { inch needle to administer } \\
\text { injection. } \\
\text { All animals were premedicated } 30-45 \text { minutes prior to induction with } \\
0.025 \mathrm{mg} / \mathrm{kg} \text { acepromazine, } 0.3 \mathrm{mg} / \mathrm{kg} \text { morphine, mixed in the same } \\
\text { syringe and given IM lumbar and cervical epaxial muscles. } \\
\text { All animal were induced with } 2-4 \mathrm{mg} / \mathrm{kg} \text { propofol IV, to effect to } \\
\text { allow endotracheal intubation. All animals also received a } \\
\text { meloxicam (NSAID) dose of } 0.2 \mathrm{mg} / \mathrm{kg} \text { IV after induction of } \\
\text { anaesthesia. } \\
\text { All animals were maintained with isoflurane. Procedures were } \\
\text { started within } 5 \text { minutes of lidocaine injection. Final year } \\
\text { veterinary students performed procedure under supervision. }\end{array}$ \\
\hline Study design: & Double Blinded Randomised Control Prospective Study \\
\hline Outcome studied: & $\begin{array}{l}\text { Parameters monitored during the procedure every } 5 \text { minutes prior } \\
\text { to surgery, every } 3 \text { minutes and during surgical events: } \\
\text { intratesticular injection, first skin incision, exteriorisation of first } \\
\text { testes, tearing epididymis of first testes, and clamping spermatic of } \\
\text { first testes cord, exteriorisation of second testes, tearing epididymis } \\
\text { of second testes, and clamping spermatic of second testes: } \\
\text { End-tidal isoflurane concentration }\end{array}$ \\
\hline
\end{tabular}




\begin{tabular}{|c|c|}
\hline & $\begin{array}{l}\text { Capnography } \\
\text { Heart rate and rhythm } \\
\text { Arterial Oxygen saturation } \\
\text { Esophageal temperature } \\
\text { Electrocardiography } \\
12 \text { dogs had systolic measured with Doppler and } 30 \text { dogs had } \\
\text { oscillometric with systolic, diastolic and mean pressures. } \\
\text { Post-operative measurements were every half hour: } \\
\text { Short form of Glasgow composite pain scale (6 or greater got rescue } \\
\text { analgesia of morphine and removed from further analysis) - carried } \\
\text { out by anaesthetist. }\end{array}$ \\
\hline $\begin{array}{l}\text { Main findings: } \\
\text { (relevant to PICO question): }\end{array}$ & $\begin{array}{l}\text { - No overall difference in heart rate } \\
\text { - } \text { OAP changed less in group } L \text { than } S \\
\text { - } \quad \text { Respiratory rate was significantly higher in group } S \text { at an } \\
\text { earlier point than group } L \text { but both had similar respiratory } \\
\text { averages } \\
\text { - } \text { Overall values were not dissimilar with the exception of } \\
\text { fewer changes earlier in the procedure with the lidocaine } \\
\text { group } \\
\text { - } 8 / 19 \text { group } L \text { at later surgical times and } 7 / 23 \text { group } S \text { at } \\
\text { earlier surgical times required additional propofol. } \\
\text { Isoflurane was maintained at the same level in all cases with } \\
\text { the exception of one dog } \\
\text { - } \quad 7 / 19 \text { dogs in group } L \text { and } 12 / 23 \text { dogs in group } S \text { required } \\
\text { rescue analgesia. }\end{array}$ \\
\hline Limitations: & $\begin{array}{l}\text { The charts could have been better explained, particularly } \\
\text { table } 1 . \\
\text { Blood pressure measurement, Doppler and oscillometrics } \\
\text { were used that would cause an additional variable in values. } \\
\text { ANOVA (parametric) values showed no significance but } \\
\text { when Bonferroni adjustments (non-parametric) were made, } \\
\text { value was found. It seems questionable application to make } \\
\text { numbers have value. } \\
\text { - Student surgeons were doing the procedure which may not } \\
\text { be realistic to the clinical environment (in terms of } \\
\text { procedure duration) and lidocaine may have worn off before } \\
\text { procedure was complete. } \\
\text { - Lidocaine duration was biggest hindrance in author's view, } \\
\text { where longer acting bupivacaine may have been preferred } \\
\text { but has risk of toxicity if given accidentally intravascularly. }\end{array}$ \\
\hline
\end{tabular}




\section{Appraisal, application and reflection}

Examination of the whole body of studies made the effect of lidocaine extremely inconsistent. However, when taking into account the type of premedication used in the studies, a clearer picture presented itself. The most significant contribution to post-operative analgesia in routine castration of the dog and cat seems to be the analgesic used in premedication. In studies that used pure $\mu$ opioid agonists, there was less significance between control and intratesticular block groups in post-operative pain scores. In all studies where a pure $\mu$ opioid agonist was not used, there was clinical significance in the use of intratesticular blocks (to favourable effect). As our clinical scenario utilises buprenorphine, intratesticular lidocaine or bupivacaine may be indicated.

Another variable that should be further examined is the use of lidocaine versus bupivacaine as an intratesticular block. The one study that utilised pure $\mu$ opioid premeds and had positive results was the study that used bupivacaine instead of lidocaine as an intratesticular block. While there is concern about intravascular bupivacaine toxicity, bupivacaine toxicity has not been noted in any of the two studies that utilised bupivacaine(Perez et al., 2013; Stevens et al., 2013).

A further limitation of these results is in our PICO, we were focusing on pain and the use of intratesticular blocks. If this PICO were modified to isoflurane, propofol, and rescue analgesic sparing effect, our conclusion may be different. Only one study, measured isoflurane requirements based on different modalities of adjunctive analgesia(McMillan, Seymour and Brearley, 2012).

Overall, blocks led to no significantly aversive events in any of the studies, it is relatively inexpensive, and fairly easy to administer. In light of the low cost and minimal risk with inconsistent results, an argument could be made that it is still worthwhile to administer in most clinical scenarios.

\section{Methodology Section}

\begin{tabular}{|r|l|}
\hline Search Strategy & \\
\hline $\begin{array}{r}\text { Databases searched and dates } \\
\text { covered: }\end{array}$ & $\begin{array}{l}\text { PubMed (1963-07/2017) } \\
\text { VetMed Resource (CAB) (1973 - week 1 2017) } \\
\text { CAB Abstracts on OVID Platform (1973- Week } 12017)\end{array}$ \\
\hline Search terms: & $\begin{array}{l}\text { Orchiectomy AND intratesticular AND veterinary (pubmed 22 results } \\
\text { and 9 relevant) , (dog OR cat) AND intratesticular (Pubmed 46 } \\
\text { results/5 relevant), lidocaine AND castration AND (dogs OR cats) } \\
\text { (Pubmed 21/3 relevant), orchiectomy AND intratesticular (Vetmed } \\
\text { Resource and Cab Abstracts) 11 results/3 relevant }\end{array}$ \\
\hline Dates searches performed: & \begin{tabular}{l}
$17^{\text {th }}$ July 2017 \\
\hline
\end{tabular} \\
\hline
\end{tabular}

Exclusion / Inclusion Criteria

Exclusion: Anesthetic injections versus local blocks

Inclusion: English, French, Spanish, and Thai articles on intratesticular injection of local anesthetic to testicles. 


\begin{tabular}{|c|c|c|c|c|c|}
\hline \multicolumn{6}{|c|}{ Search Outcome } \\
\hline Database & $\begin{array}{c}\text { Number } \\
\text { of } \\
\text { results }\end{array}$ & $\begin{array}{l}\text { Excluded - not } \\
\text { involving lidocaine } \\
\text { intratesticular } \\
\text { injection on dogs }\end{array}$ & $\begin{array}{l}\text { Excluded - } \\
\text { duplicate }\end{array}$ & $\begin{array}{c}\text { Excluded - not local } \\
\text { anesthetic - lidocaine } \\
\text { or bupivicaine }\end{array}$ & $\begin{array}{c}\text { Total relevant } \\
\text { papers }\end{array}$ \\
\hline Pubmed & 89 & 77 & & 7 & 5 \\
\hline $\begin{array}{l}\text { VetMed } \\
\text { Resource }\end{array}$ & 11 & 3 & 3 & & 0 \\
\hline $\begin{array}{l}\text { CAB } \\
\text { Abstracts }\end{array}$ & 11 & & 11 & & 0 \\
\hline \multicolumn{5}{|c|}{ Total relevant papers when duplicates removed } & 5 \\
\hline
\end{tabular}

\section{CONFLICT OF INTEREST}

Erik Fausak is a member of the editorial board of Veterinary Evidence.

This paper underwent a rigorous peer-review process as per our normal reviewing guidelines of inviting a minimum of two external reviewers. The identity of the Associate Editor handling the paper has not been disclosed to the author. The final decision to accept this paper rested with the Editor-in-chief.

All other authors declare no conflict of interest.

\section{REFERENCES}

1. Huuskonen, V. et al. (2013) 'Intratesticular lidocaine reduces the response to surgical castration in dogs', Veterinary Anaesthesia and Analgesia, 40(1), pp. 74-82. doi: http://dx.doi.org/10.1111/j.1467$\underline{2995.2012 .00775 . x}$

2. McMillan, M. W., Seymour, C. J. and Brearley, J. C. (2012) 'Effect of intratesticular lidocaine on isoflurane requirements in dogs undergoing routine castration', Journal of Small Animal Practice, 53(7), pp. 393-397. doi: http://dx.doi.org/10.1111/j.1748-5827.2012.01233.x

3. Perez, T. E. et al. (2013) 'Effects of intratesticular injection of bupivacaine and epidural administration of morphine in dogs undergoing castration', Journal of the American Veterinary Medical Association, 242(5), pp. 631-642. doi: http://dx.doi.org/10.2460/javma.242.5.631

4. Rodriguez, A. R. Á., Gaviria, E. F. B. and Bonilla, D. F. E. (2016) 'Evaluación del efecto analgésico de la 
lidocaína vía intratesticular o intrafunicular en perros sometidos a orquiectomia electiva bajo un protocolo de anestesia disociativa', REDVET. Revista Electrónica de Veterinaria. Veterinaria Organización, 17(9), pp. 1-16.

5. SAMMARCO, J.L., CONZEMIUS, M.G., PERKOWSKI, S.Z., WEINSTEIN, M.J., GREGOR, T.P. and SMITH, G.K., 1996. Postoperative analgesia for stifle surgery: a comparison of intra-articular bupivacaine, morphine, or saline. Veterinary Surgery, 25(1), pp.59-69. doi: http://dx.doi.org/10.1111/j.1532950X.1996.tb01377.x

6. Stevens, B. J. et al. (2013) 'Comparison of the effect of intratesticular lidocaine/bupivacaine vs. saline placebo on pain scores and incision site reactions in dogs undergoing routine castration', The Veterinary Journal, 196(3), pp. 499-503. doi: http://dx.doi.org/10.1016/j.tvjl.2012.11.019 


\section{EVIIDEFeE

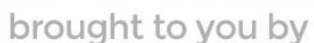 \\ RCVS KNOWLEDGE}

\section{Intellectual Property Rights}

Authors of Knowledge Summaries submitted to RCVS Knowledge for publication will retain copyright in their work, and will be required to grant RCVS Knowledge a non-exclusive license of the rights of copyright in the materials including but not limited to the right to publish, re-

publish, transmit, sell, distribute and otherwise use the materials in all languages and all media throughout the world, and to license or permit others to do so.

\section{Disclaimer}

Knowledge Summaries are a peer-reviewed article type which aims to answer a clinical question based on the best available current evidence. It does not override the responsibility

of the practitioner. Informed decisions should be made by considering such factors as individual clinical expertise and judgement along with patient's circumstances and owners' values. Knowledge Summaries are a resource to help inform and any opinions expressed within the Knowledge Summaries are the author's own and do not necessarily reflect the view of the RCVS Knowledge. Authors are responsible for the accuracy of the content. While the

Editor and Publisher believe that all content herein are in accord with current recommendations and practice at the time of publication, they accept no legal responsibility

for any errors or omissions, and make no warranty, express or implied, with respect to material contained within.

For further information please refer to our Terms of Use.

RCVS Knowledge is the independent charity associated with the Royal College of Veterinary Surgeons (RCVS). Our ambition is to become a global intermediary for evidence based veterinary knowledge by providing access to information

that is of immediate value to practicing veterinary professionals and directly contributes to evidence based clinical decision-making.

\section{https://www.veterinaryevidence.org/}

RCVS Knowledge is a registered Charity No. 230886.

Registered as a Company limited by guarantee in England and Wales No. 598443.

Registered Office: Belgravia House, 62-64 Horseferry Road, London SW1P 2AF

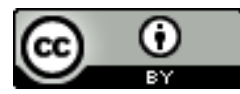

This work is licensed under a Creative Commons Attribution 4.0 International License 